\title{
APLIKASI EDIBLE COATING DARI PATI UMBI PORANG DENGAN PENAMBAHAN EKSTRAK LENGKUAS MERAH PADA BUAH LANGSAT
}

\author{
Application Of Porang Starch Based Edible Coating with Tumeric Extract on Langsat
}

\author{
Nurlatifah $^{1}$, Dewi Cakrawati ${ }^{2}$, Puji R. Nurcahyani ${ }^{3}$ \\ 1,2,3 Program Studi Pendidikan Teknologi Agroindustri, \\ Fakultas Pendidikan Teknologi dan Kejuruan \\ *Korespondensi: dewicakrawati@upi.edu
}

\begin{abstract}
ABSTRAK
Langsat merupakan salah satu buah tropis yang bersifat klimaterik sehingga memiliki umur simpan yang rendah. Penelitian ini bertujuan untuk mengetahui pengaruh aplikasi edible coating dengan penambahan ekstrak lengkuas merah pada karakteristik fisik kimia buah langsat. Penelitian dilakukan dengan metode dekstriptif dengan mengamati karakteristik fisik dan kimia buah langsat dengan edible coating meliputi warna, laju respirasi, total asam tertitrasi, tekstur, analisis total mikroba dan analisis susut bobot. Analisis karakteristik fisik hasil susut bobot menunjukkan bahwa dengan pelapisan edible dapat mengurangi terjadinya penurunan susut bobot, dapat mempertahankan tekstur buah dan pada warna buah yang dilapisi dengan edible dapat menghasilkan buah yang memiliki warna yang lebih gelap. Analisis karakteristik kimia buah langsat, bahwa pelapisan yang dilakukan pada buah langsat dapat mengurangi penurunan asam tertitrasi dan juga dapat menekan proses laju respirasi. Pada total jumlah mikroba pelapisan edible dapat meminimalisir kontaminasi pada kulit buah. Berdasarkan penelitian bahwa pada hari ke-6 terjadi respiraasi anerob yang menyebabkan tingginya laju respirasi, kadar TAT dan juga tingginya kelunakan yang terjadi pada buah yang tidak dilapisi dengan edible.
\end{abstract}

Kata kunci: langsat, porang, edible coating, ekstrak lengkuas

\begin{abstract}
Langsat is a climateric tropical fruit thus have a low shelf life. The study aimed to determine the effect of edible coating applications with the addition of red ginger extract on the physical characteristics of the olive fruit chemistry. Research carried out by methods dekstriptif by observing the physical and chemical characteristics of olive fruit with edible coating covering color, respiration rate, total acid tertitrasi, texture, total microbial analysis and analysis of weight loss. Analysis of the physical characteristics of weight loss results demonstrate that the edible coating could reduce the decline in weight loss, it can maintain the fruit texture and the color of the fruit is coated with edible can produce fruit that has a darker color. Analysis of the chemical characteristics of the olive fruit, that the coating is carried out on olive fruit can reduce the decline tertitrasi acid and also can suppress the process of respiration rate. In total the number of microbial coating to minimize contamination of edible rind. Based on research that on the 6th day happen respiraasi causing the high rate anaerobic respiration, TAT and also high levels of softness that occurs in fruits that are not coated with edible.
\end{abstract}

Keywords : langsat, edible coating, galangal, 


\section{PENDAHULUAN}

Langsat (Lansium domesticum) merupakan buah tropis yang tergolong buah (klimaterik) dengan laju respirasi yang tinggi sehingga memiliki masa simpan yang singkat. Menurut Paul (2014), langsat memiliki umur simpan yang singkat, dan akan berwarna coklat setelah 4 hari penyimpanan pada suhu ruang. Kerusakan pada buah langsat ditandai dengan berubahnya kulit buah menjadi kehitam-hitaman yang kemudian di susul dengan melunaknya tekstur buah. Selain itu kerusakan sering terjadi yaitu pembusukan yang disebabkan oleh mikroorganisme. Maka dari itu diperlukan cara agar dapat mempertahankan kualitas buah dalam waktu yang cukup lama, salah satunya dengan pelapisan menggunakan edible coating.

Buah mengandung kadar air yang tinggi. proses pematangan menyebabkan kehilangan. air yang berpengaruh pada kehilangan gula dalam sel dan pelunakan buah serta perubahan warna pada kulit buah untuk memperpanjang masa simpan buah tergantung dari 3 faktor yaitu penurunan desikasi, penurunan proses fisiologi yang berhubungan dengan kematangan dan pembusukan dan penurunan tingkat pertumbuhan mikroorganisme. hal ini dapat dilakukan dengan penurunan suhu penyimpanan serta memberikan lapisan film untuk menyediakan barier bagi oksigen atau transmisi uap air (Yaman \& Bayindirli, 2001).

Edible coating merupakan salah satu metode pengemasan yang banyak diaplikasikan pada sayur dan buah saat ini karena dapat memperlambat kematangan dan metabolisme buah setelah pemanenan sehingga dapat memperpanja ng umur simpan buah selama penyimpanan. Penelitian Gunawan (2009) menunjukkan aplikasi edible coating berbasis pati sagu dengan penambahan vitamin C pada paprika mampu mempertahankan masa simpan paprika selama 3-7 hari, sedangkan penelitian Pokatong dkk (2014) menunjukkan edible coating yang terbuat dari pati gembili dengan penambahan sorbitol dapat menambah masa simpan buah strawberry selama 4 hari. Selain dapat memperpanjang masa simpan, edible coating juga dapat meningkatkan nilai gizi bahan pangan serta dapat memperbaiki kenampakan buah.

Edible coating terbuat dari bahan yang dapat membuat lapisan film seperti bahan hidrokoloid (seperti protein, polisakarida, dan alginat), lemak (seperti asam lemak, acylglycerol, dan lilin), dan bahan campuran lainnya yang aman digunakan pada produk makanan. Bahan dasar pembuatan Edible yang telah banyak diteliti adalah berbasis pati-patian. Salah satu jenis pati yang dapat digunakan menjadi bahan dasar pembuatan edible yaitu pati porang. Keuntungan penggunaan pati porang dalam pembuatan edible coating yaitu dapat menghasilkan coating yang memiliki daya rekat yang kuat, berdasarkan sifat merekatnya, pati porang lebih baik jika dibandingkan dengan perekat lain seperti jagung dan beras karena mengandung glukomanan.

Edible coating berbasis pati mempunyai kelemahan, yaitu resistensinya terhadap air rendah dan sifat penghalang terhadap uap air juga rendah karena sifat hidrofilik pati dapat memengaruhi stabilitas dan sifat mekanisnya (Garcia et al. 2011). Salah satu cara agar dapat meningkatkan karakteristik fisik maupun fungsional dari edible coating berbasis pati yaitu adanya penambahan bahan lain yang bersifat hirofobik dan atau yang memiliki sifat antimikroba. Maka dari itu dalam pembuatan edible coating berbasis pati diperlukan penambahan bahan lain, salah satunya menggunakan bahan yang mengandung senyawa antimikroba seperti lengkuas.

Lengkuas merupakan jenis rempah-rempah memiliki kandungan minyak atsiri yang dapat berperan sebagai senyawa anti mikroba, selain itu juga bahan baku lengkuas mudah didapat dan murah. Berdasarkan penelitian Utami dkk (2012) penambahan ekstrak lengkuas merah pada pembuatan edible coating mampu menghambat pertumbuhan Pseudomonas putida dan Pseudomonas fluorescen. Penelitian yang dilakukan oleh Sukandar et al. (2009) dan Yulinar dkk (2013) membuktikan bahwa minyak atsiri dari rimpang lengkuas merah Alpinia purpurat K. Schum dapat menghambat aktivitas bakteri Bacillus cereus dan Pseudomonas aeruginosa.

Berdasarkan uraian diatas perlu dilakukan penelitian mengenai pengaruh aplikasi Edible coating berbasis pati umbi porang dengan penambahan ekstrak lengkuas merah terhadap karakteristik fisik dan kimia buah Langsat selama penyimpanan 12 hari. 


\section{METODE}

Alat yang digunakan dalam penelitian ini adalah erlenmeyer, corong, mikropipet, autoklaf, oven, laminary air flow, beaker glass, stirrer, hot plate, timbangan analitik, termometer, sterofoam, keranjang buah, statif, cawan porselin, cawan petri, pompa udara, inkubator, bunsen, tabung reaksi dan rak tabung reaksi, erlenmeyer $100 \mathrm{ml}$ dan $250 \mathrm{ml}$, toples kaca, selang plastik, pipet, gelas kimia, gelas ukur, kertas label, tissue, kertas saring, kapas, swab steril, alumunium foil dan kamera.

Bahan yang digunakan dalam penelitian ini adalah 80 buah Langsat yang diperoleh dari Pasar Sederhana, Sukajadi Bandung dengan ukuran dan warna yang umumnya seragam, tidak memar, tidak busuk, dan memiliki kenampakan yang mulus dan larutan ediblecoating pati porang dengan penambahan ekstrak lengkuas. Sedangkan, bahan yang digunakan untuk analisis antara lain indikator Phenoptalen, $\mathrm{NaOH} 0.1 \mathrm{~N}, \mathrm{NaCl}, \mathrm{KOH}, \mathrm{HCL} 0.1 \mathrm{~N}$, akuades, alkohol 95\% dan Nutrien Agar (NA)

Pembuatan Edible coating

Tepung porang dan ekstrak lengkuas ditimbang dengan konsentrasi masing-masing bahan adalah $1 \%$ dari berat air. Gliserol dan CMC ditimbang $0,5 \%$ dari berat tepung porang. Tepung porang dibuat suspensi dengan penambahan akuades sebanyak $750 \mathrm{ml}$. Dilakukan pemanasan

dengan hot plate stirer selama 30 menit pada suhu $85^{\circ} \mathrm{C}$ sampai kenampakan homogen, kemudian ditambahkan $\mathrm{CMC}$, gliserol, dan ekstrak lengkuas sampai dihasilkan tekstur yang cukup baik untuk pencelupan buah.

Pencelupan

Buah Langsat dibersihkan dari kotoran, kemudian disemprot dengan alkohol dan dikeringkan. Langsat yang telah kering kemudian dicelupkan dalam larutan Edible coating pati porang yang ditambah ekstrak lengkuas. Pencelupan buah Langsat dilakukan selama 30 detik kemudian buah digantung pada statip untuk dikeringkan dengan bantuan alat pengering. (Nur'aini dkk, 2015)

Penyimpanan

Buah yang telah kering kemudian disimpan pada wadah styrofoam pada suhu ruang. Pendugaan umur simpan dilakukan dengan melakukan pengujian yang terdiri dari uji susut bobot, uji Total Asam Tertitrasi dan uji laju respirasi yang dilakukan setiap hari dari hari ke-0 sampai buah tidak dapat digunakan lagi untuk pengujian pada penelitian ini dilakukan target selama 12 hari, sedangkan uji TPC, uji tekstur dan uji warna dilakukan pada hari ke 0 , hari ke 3 , hari ke 6 , hari ke 9 dan hari ke 12. (Niam, 2009)

\section{Analisis Susut Botot}

Pengukuran susut bobot dilakukan secara gravimetri, yaitu membandingkan selisih bobot sebelum penyimpanan dan sesudah penyimpanan. Kehilangan bobot selama penyimpanan dapat dihitung dengan rumus sebagai berikut (AOAC, 1995):

$$
\text { Susut bobot }=\frac{\text { berat awal }- \text { berat akhir }}{\text { berat awal }} \times 100 \%
$$

\section{Total Asam Tertitrasi}

Asam titrasi dapat di uji dengan mengambil sampel yang dihaluskan kemudian di larutkan pada air dengan perbandingan 1:10, lalu diberi tetesan pp sebanyak 3 tetes dan titrasi dengan $\mathrm{NaOH}$ 0,1 N sampai warna merah mudah menjadi hilang. Hasil persentase dalam gram memunjukan jumlah asam malat/ 100 gram langsat. (Souza et al, 2015) rumus TAT sebagai berikut:

$$
\text { total asam }=\frac{V \times N \times F p}{w} \times 100 \%
$$

Dimana $\mathrm{V}=$ volume Titrasi $(\mathrm{ml} \mathrm{NaOH}), \mathrm{N}=$ normalisasi $\mathrm{NaOH}, \mathrm{Fp}=$ Faktor Pengencer, $\mathrm{W}=$ Berat sampel 


\section{Uji Laju Respirasi}

Respirasi buah di ukur dengan mengukur jumlah $\mathrm{CO}_{2}$ yang dikeluarkan. Sampel Edible dan kontrol di tempatkan pada jar kedap udara dengan suhu yang digunakan adalah suhu ruang. Perhitungan dilakukan setiap hari selama 11 hari. Terdapat dua perlakuan pada pengujian laju respirasi: (1) laju respirasi Langsat kontrol tanpa edible coating, (2) Laju Respirasi Langsat dengan edible coating. Proses pengukuran laju respirasi, mula-mula disiapkan bahan dan reagen antara lain salak, $\mathrm{CaCl}_{2}$, Larutan phenoftalein $1 \%$, larutan $\mathrm{HCL} 0.1 \mathrm{~N}$, larutan $\mathrm{NaOH} 0.1 \mathrm{~N}$, larutan $\mathrm{KOH} 2 \mathrm{~N}$, Larutan $\mathrm{KOH} 1$ $\mathrm{N}$. Kemudian alat-alat yang digunakan seperti pompa udara, selang plastik, jar, erlenmeyer.

Rumus Laju Respirasi sebagai berikut:

$$
\mathrm{CO}_{2}(\mathrm{mg} / \mathrm{kg} / 1 \mathrm{jam})=\frac{(\mathrm{ml} \mathrm{HCL} \quad \text { lanko-contoh }) \times N \text { HCL } \times 44}{k g \text { bahan } \times 2}
$$

\section{Analisis Total Mikroba}

Analisis mikroba dilakukan dengan mengambil sampel daging langsat sebanyak 1 gram yang dilarutkan dalam larutan $\mathrm{NaCl}$ fisiologis dan dihomogenkan dengan vortex. Kemudian dilakukan pengenceran sampai dengan $10^{-5}$. Satu mililiter dari pengenceran $10^{-3}-10^{-5}$ ditanam dalam media yang telah di isi oleh media agar yaitu Nutrien agar sebanyak $15 \mathrm{ml}$. Teknik penanaman sampel dengan cara pour plate pada petri dish sehingga sampel tersebar rata pada media. Setelah sampel tersebar merata cawan dibalik dan dilakukan inkubasi selama 48 jam pada suhu $37^{\circ} \mathrm{C}$. Seluruh analisis dilakukan sebanyak dua kali ulangan dengan hasil akhir dalam satuan (log CFU/g). (Souza et al, 2015) Rumus perhitungan TPC sebagai berikut:

$$
\text { Koloni/ } \mathrm{ml}=\text { jumlah koloni percawan } \frac{1}{\text { faktor pengenceran }}
$$

\section{Uji Warna}

Uji warna dilakukan dengan menempatkan buah langsat dalam kotak dengan dasar berwarna hitam lalu difoto dengan menggunakan kamera 8 mega pixels lalu dilakukan pengukuran dan perhitungan warna menggunakan sofware adobe photoshop.

\section{HASIL DAN PEMBAHASAN}

\section{Analisis Susut Bobot}

Susut bobot merupakan salah satu indikator penurunan mutu buah langsat. Pengukuran susut bobot dilakukan untuk mengetahui pengaruh penggunaan coating dan lama penyimpanan terhadap penyusutan bobot buah langsat selama 11 hari. Penurunan susut bobot merupakan salah satu faktor yang mempercepat terjadinya penurunan mutu buah. Penyusutan susut bobot langsat sangat dipengaruhi oleh proses respirasi dan transpirasi yang terjadi. Pengukuran susut bobot pada buah bertujuan untuk mengetehui besarnya pengurangan berat buah selama proses penyimpanan yang disebabkan terjadi penguapan air. Menurut Hernandez-Munoz, et al. (2008), kehilangan air dalam buah sangat berkaitan erat dengan laju respirasi dan transpirasi melalui kulit buah. susut bobot diakibatkan oleh respiasi yang menyebabkan buah kehilangan setiap atom karbon pada setiap siklusnya.(Yaman \& Bayindirli, 2001).

\section{Total Asam Tertitrasi}

Perubahan kandungan total asam organik pada buah dan sayuran menandai terjadinya perubahan kimia pada buah tersebut. Asam organik yang terdapat dalam buah yaitu asam sitrat, asam malat, oksalat, asam tartarat, asam quinan, asam khlorogenat, asam shikimat dan asam askorbat. Asam organik yang terkandung dalam buah langsat adalah asam malat (Sitorus dkk, 2012). Bari et al (2006) menyatakan bahwa total asam buah akan meningkat pada tingkat kematangan awal dan akan menurun lagi pada buah yang mendekati busuk. total asam tertitrasi menurun seiring peyimpangan. tetapi meningkat dengan peningkatan konsentrasi edible coating yang digunakan. Asam organik merupakan substrat bagi reaksi enzimatis pada proses respirasi., penurunan kadar asam dan peningkatan $\mathrm{pH}$ diharapkan sselama penyimpanan. 


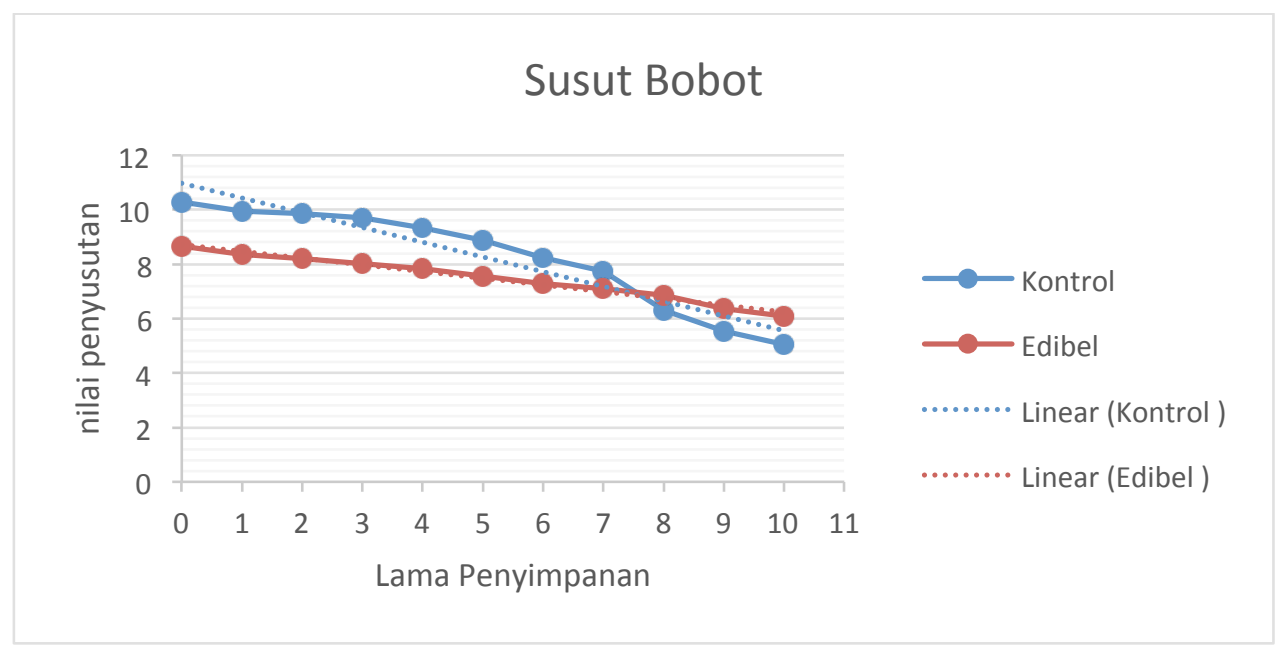

Gambar 1. Grafik Nilai rata- rata Susut Bobot Buah Langsat

Nilai total asam tertitrasi pada buah langsat yang tidak dilapisi edible coating berfluktuasi selama penyimpanan 11 hari. Secara umum nilai total asam tertitrasi pada buah langsat dengan dilapisi edible coating lebih rendah dibanding nilai total asam tertitrasi buah langsat tanpa edible coating. Menurut Yaman \& Bayindirli, (2001), total asam tertitrasi menurun seiring peyimpangan. tetapi meningkat dengan peningkatan konsentrasi edible coating yang digunakan. Pelapisan edibel coating menurunkan laju respirasi sehingga asam organik tidak banyak digunakan untuk respirasi sehingga penurunan kandungan asam organik tidak terlalu besar. Pelapisan edibel coating menurunkan laju respirasi sehingga asam organik tidak banyak digunakan untuk respirasi sehingga penurunan kandungan asam organik tidak terlalu besar.

Fluktuasi nilai total asam pada buah juga diduga karena adanya pertumbuhan bakteri yang disebabkan oleh adanya respirasi anaerob akibat pelapisan edible yang menyebabkan berkurangnya atau bahkan tidak adanya kandungan oksigen sehingga memicu pertumbukan mikroorganisme yang akan menghasilkan alkohol ataupun asam. Peningkatan total asam yang biasa terjadi pada produk olahan sayur dan buah karena adanya aktivitas bakteri pemecah gula yang menghasilkan asam, di antaranya Bacillus, Clostridium, Propionibacterium, dan Acetobacter (Dewandari dkk, 2009). Dengan demikian penyebab terjadinya fluktuasi nilai TAT pada buah langsat yang tidak dilapisi edible dan yang dilapisi ediblecoating karena adanya aktivitas mikroorganisme pada buah.

\section{Total Asam Tertitrasi}

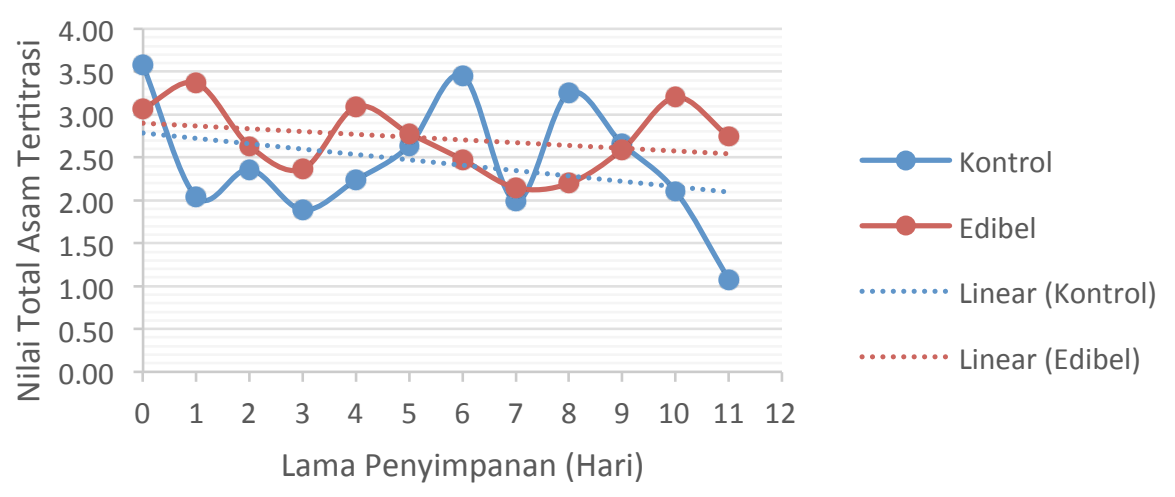

Gambar 2. Nilai Total Asam Tertitrasi selama penyimpanan Buah Langsat 


\section{Laju Respirasi}

Respirasi merupakan proses penyerapan oksigen untuk memecah subsrat komplek menjadi senyawa sederhana agar dapat digunakan dalam pembentukan energi. Substrat yang dapat digunakan dalam proses respirasi adalah pati, gula, dan asam organik selain itu lemak dan protein juga dapat digunakansebagai substrat pada proses respirasi. Proses respirasi ini menghasilkan gas $\mathrm{CO}_{2}$ dan $\mathrm{H}_{2} \mathrm{O}$. Buah langsat merupakan buah klimaterik yang memiliki laju respirasi yang tinggi.

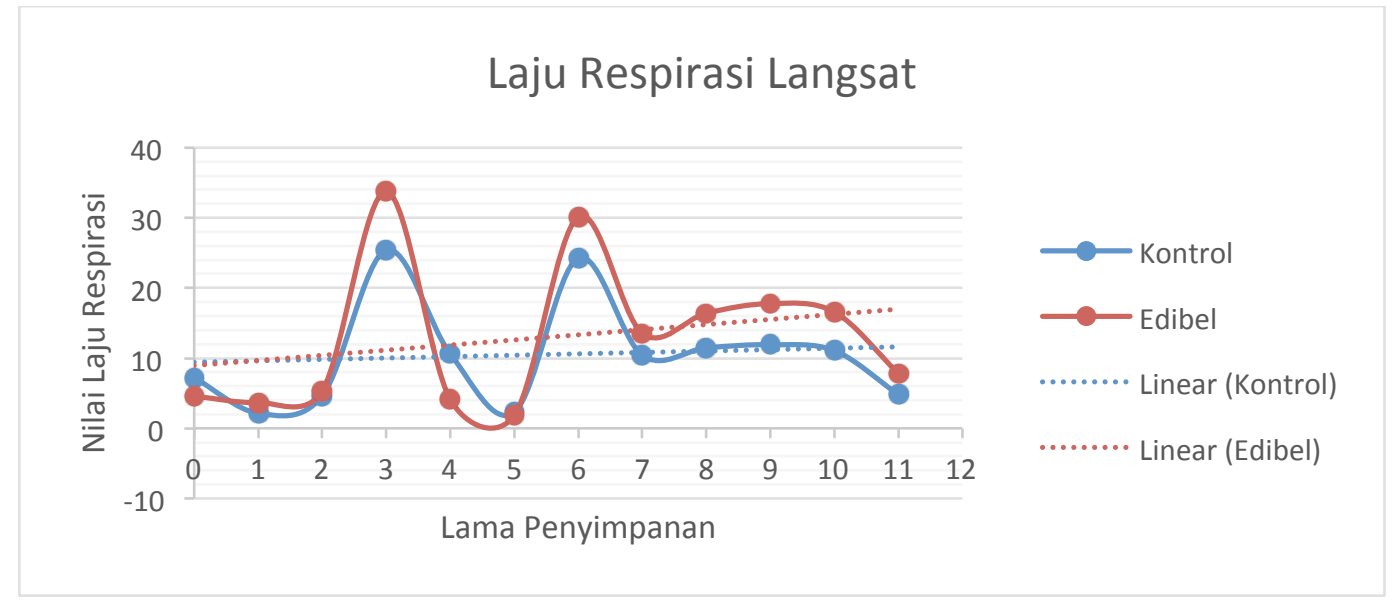

Gambar 3. Laju respirasi Buah Langsat dengan dan Tanpa Edible Coating

Menurut Olivas et al (2009) aplikasi edible coating berfungsi untuk menekan laju respirasi buah, namun terdapat penelitian yang menunjukan bahwa aplikasi edible coating pada bahan pangan menyebabkan terjadinya respirasi anaerob. Hal ini dapat juga terjadi karena lapisan edible coating pada buah terlalu tebal sehingga buah mengalami respirasi anaerob karena $\mathrm{CO}_{2}$ yang dihasilkan terhambat keluar udara oleh lapisan film yang menyebabkan respirasi anaerob. Respirasi tersebut dapat menghasilkan aroma yang menyimpang dan percepatan pematangan.Berdasarkan hal tersebut maka respirasi yang terjadi tanpa menggunakan $\mathrm{O}_{2}$ (anaerob) dapat menyebabkan sel melakukan perombakan di dalam buah itu sendiri yang dapat mengakibatkan proses pembusukan lebih cepat dari keadaan yang normal.

\section{Analisis Total Mikroba}

Buah dapat terkontaminasi mikroorganisme yang menurut Eni et al (2010) dapat terjadi akibat kontak dengan tanah, debu, air, saat proses panen atau pada saat pasca panen. Ekstrak lengkuas merah mampu menghambat pertumbuhan mikroorganisme Pseudomonas putida dan Pseudomonas fluorescen,seperti dilaporkan Utami et al (2010). Hemela (2006) menambahkan ekstrak lengkuas mampu menghambat pertumbuhan jamur Microsporum Canis dan Tricophyton Mentagrophytes dan pada penelitian yang dilakukan oleh Sukandar et al. (2009) dan Yulinar dkk (2013) membuktikan bahwa minyak atsiri dari rimpang lengkuas merah Alpinia purpurat K. Schum dapat menghambat aktivitas bakteri Bacillus cereus dan Pseudomonas aeruginosa.

Hasil penelitian menunjukkan Buah langsat yang dilapisi edible coating memiliki nilai total mikroba yang lebih rendah dibandingkan dengan buah langsat yang tidak dilapisi edible coating, seperti disajikan pada Gambar 4. 


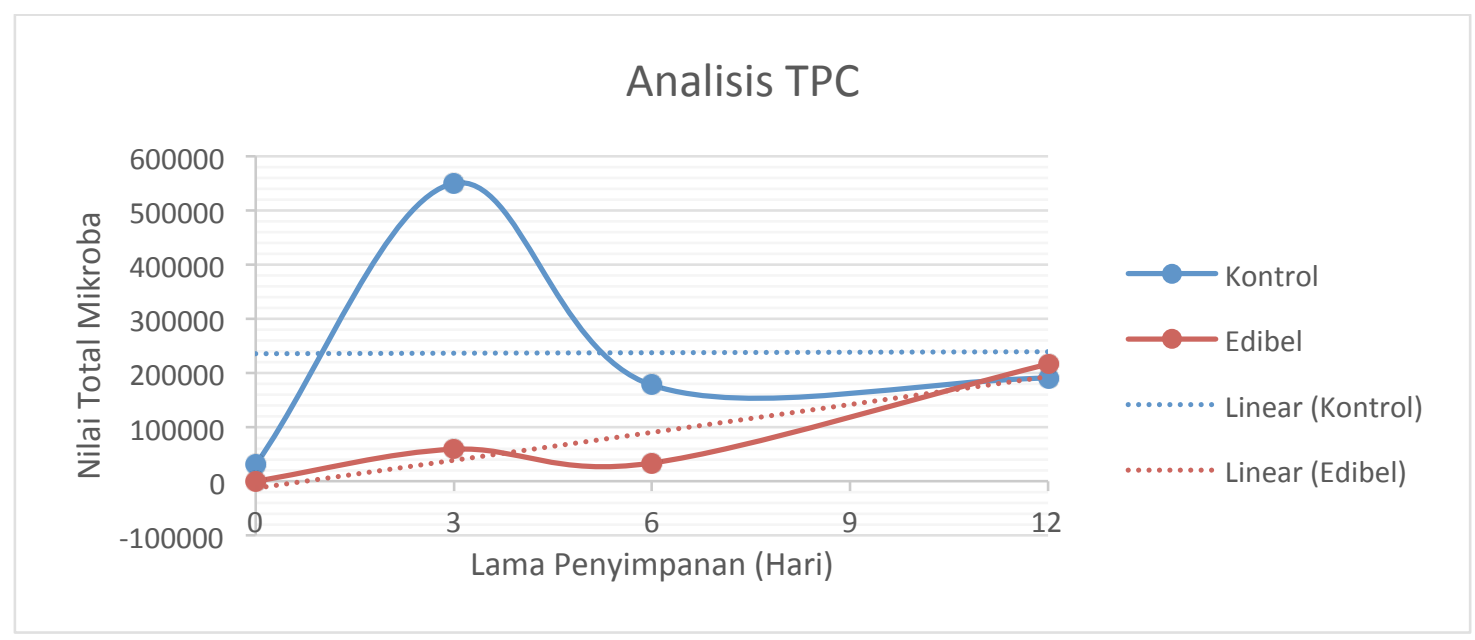

Gambar. 4 Grafik Nilai rata-rata Total Mikroba

\section{Warna}

Warna merupakan salah satu parameter dari kualitas suatu yang diamati dalam hal penerimaan konsumen. Analisis warna pada buah langsat dilakukan dengan menggunakan metode CIE-L*a*b* yang dirancang menyerupai persepsi penglihatan manusia dengan menggunakan tiga komponen yaitu $L$ sebaga luminance (pencahayaan) serta a dan bebagai dimensi warna yang berlawanan Indriyani, 2012). Analisis $L^{*} a^{*} b^{*}$ disajikan pada Gambar 5.

Warna buah langsat mengalami penurunan kecerahan selama penyimpanan. Buah langsat dengan aplikasi edible coating memiliki warna lebih gelap karena warna edible coating dengan penambahan ekstrak lengkuas merah memiliki warna merah.

a.

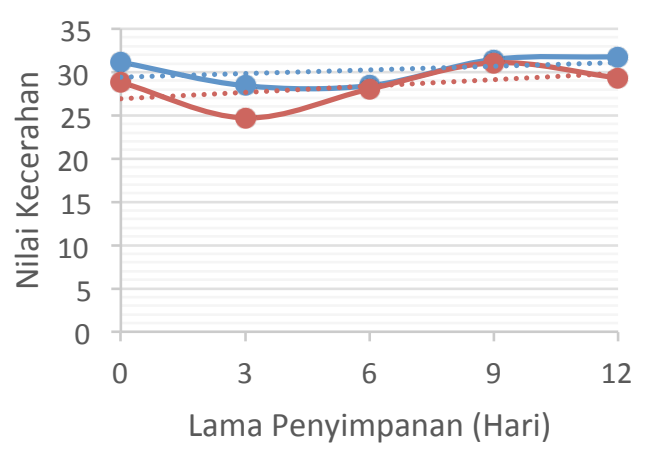

$a^{*}$

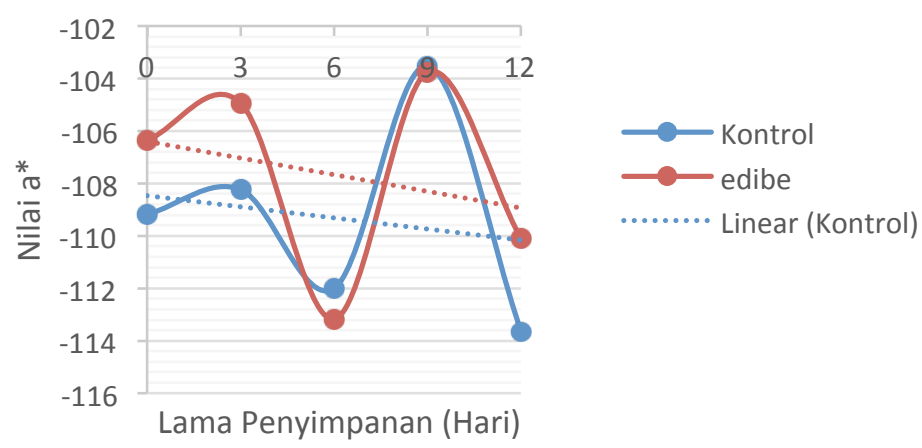

Gambar 5. Grafik

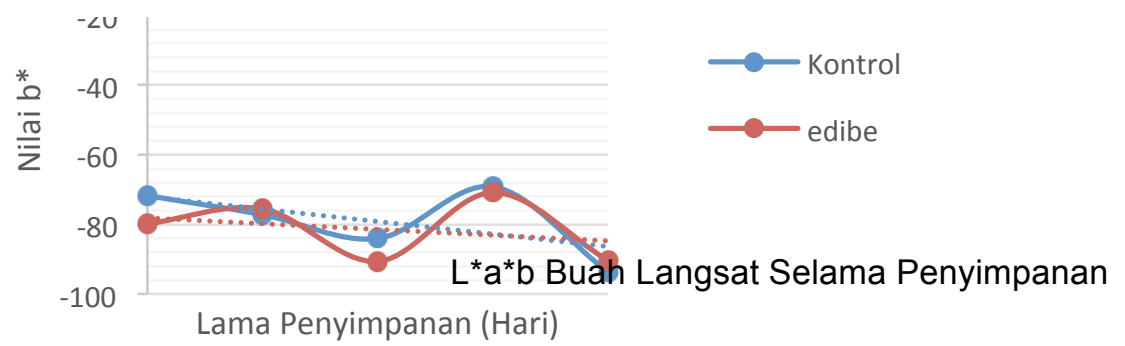

Langsat memiliki pigmen klorofil yang akan memudar selama pematangan sehingga menyebabkan perubahan warna dari hijau menjadi kuning. Semakin lama waktu penyimpanan, kerusakan jaringan kulit yang terjadi akibat proses respirasi dan transpirasi menyebabkan adanya kontak antara senyawa polifenol dengan oksigen. Dengan bantuan enzim polifenol oksidase, reaksi pencoklatan enzimatis segera terjadi yang menghasilkan senyawa quinon berwarna coklat (Muchtadi, 2011) 


\section{KESIMPULAN}

Pelapisan buah langsat dengan edible coating dapat mengurangi terjadinya penurunan susut bobot, dan tekstur buah tetapi menyebabkan warna buah menjadi lebih gelap. Pelapisan buah lansat dengan edible coating juga menekan laju respirasi dan dan mengurangi kontaminasi sehingga umur simpan buah langsat lebih lama dibanding buah langsat tanpa edible coating.

\section{DAFTAR PUSTAKA}

Budiman. (2011). Aplikasi Pati Singkong sebagai Bahan Baku Edible Coating untuk Memperpanjang Umur Simpan Pisang Cavendish. Skripsi. FTP. IPB.

Garcia, N.L., L. Ribbon, A. Dufresne, M. Aranguren, and S. Goyanes. 2011. Effect of glycerol on the morphology of nanocomposites made from thermoplastic starch and starch nanocrystals. Carbohydrate Polymers 84(1): 203-210

Gunawan, V. 2009. Formulasi Aplikasi Edible Coating Berbasis Pati Sagu dengan Penambahan Vitamin C pada Paparika. Skripsi. Fakultas Teknologi Pertanian IPB

Handajani, NS, Tjahjadi Purwoko. 2008. Aktivitas Ekstrak Rimpang Lengkuas (Alpinia galanga) terhadap Pertumbuhan Jamur Aspergillus spp. Penghasil Aflatoksin dan Fusarium moniliforme.Biodiversitas Vol. 9, No. 3, Juli 2008, hal. 161-164

Hernández-Muñoz, P., Almenar, E., Del Valle, V., Velez, D., \& Gavara, R. (2008). Effect of chitosan coating combined with postharvest calcium treatment on strawberry (Fragariax ananassa) quality during refrigerated storage. Food Chemistry, 110(2), 428-435.

Hernani, Tri, M. dan Christina, W. (2007). Pemilihan pelarut pada pemurnian ekstrak lengkuas (Alpinia galanga) secara ekstraksi. J.Pascapanen 4(1) 2007: 1-8

Marıa, L., Flores-Lo'pez., Miguel A., Cerqueira., Diana Jasso de Rodrı 'guez., dan Anto'nio A,Vicente. (2015). Perspectives on utilization of edible coatings and nano-laminate coatings for extension of postharvest storage of fruits and vegetables. Food Eng Rev

Muchtadi, T.R., Sugiyono \& F. Ayuningtyas. 2010. Ilmu Pengetahuan Bahan Pangan. Bandung: Alfabeta.

Olivas, GI., dan Barbosa-Cánovas GV (2009). Edible Films and Coatings for Fruits and Vegetables. Springer Science Business Media

Paul, RE. 2014. Longkong, Duku, And Langsat: Postharvest Quality-Maintenance Guidelines. Fruit, Nut, and Beverage Crops.

Pokatong, WDR., Carolina Lestari, dan Titri S. 2014. Mastuti. Pemanfaatan pati gembili (Dioscorea esculenta lour. Burkill) dengan penambahan plasticizer sebagai edible coating pada stroberi (Fragaria ananassa). Prosiding SNST ke-5 Tahun 2014. Jurusan Teknologi Pangan, Fakultas Sains dan Teknologi, Universitas Pelita Harapan

Rizka, Hezmela. (2006). Daya antijamur ekstrak lengkuas merah (Alpinia purpurata k. Schum) dalam sediaan salep. Skripsi. Fakultas Teknologi Pertanian Institut Pertanian Bogor Bogor

Sukandar, D., N. Radiastuti, S. Utami. 2009. Aktivitas Minyak Atsiri Rimpang Lengkuas Merah (Alpinia purpurata) Hasil Distalasi. Jurnal Biologi Lingkungan. 3(2): 94-100.

Souza, Marthyna P. \& Antônio F. M. Vaz \& Miguel A. Cerqueira \& José A. Texeira \& António A. Vicente \& Maria G. Carneiro-da-Cunha. (2015). Effect of an edible nanomultilayer coating by electrostatic self-assembly on the shelf life of fresh-cut mangoes. Food Bioprocess Technol, 8:647-654.

Utami, Rohula , Kawiji , Edhi Nurhartadi. 2012. Inkorporasi Minyak Atsiri Jahe Merah dan Lengkuas Merah pada EdibleFilm Tapioka. Seminar Nasional IX Pendidikan Biologi UNS

Yulinar, Dirayah R. Husain, Asadi Abdullah. 2013. Bioaktivitas minyak atsiri rimpang lengkuas merah alpinia purpurata $k$. Schum terhadap pertumbuhan bakteri Bacillus cereus dan Pseudomonas aeruginosa. Jurusan Biologi FMIPA Universitas Hasanuddin

Yaman, Ö., \& Bayindirli, L. (2001). Effects of an edible coating, fungicide and cold storage on microbial spoilage of cherries. European Food Research and Technology, 213(1), 53-55. http://doi.org/10.1007/s002170100334 